Iranian EFL learners' preferred oral corrective feedback:

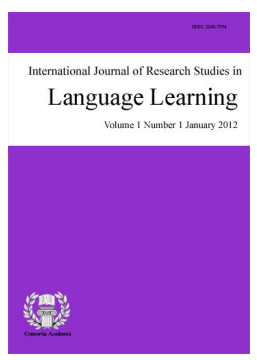

ISSN: $2243-7754$ Online ISSN: 2243-7762

OPEN ACCESS Hassaskhah, Jaleh

English Language and Literature, Guilan University, Iran (hassaskhahjaleh@yahoo.com)

\title{
Abstract
}

The purpose of this study was to investigate Iranian EFL learners' opinions about effective oral corrective feedback practices with regard to their level of anxiety. To this end, two self-reporting questionnaires were used to collect the required data. The rating scale was a five point Likert scale. The results of chi-square test indicated that there were significant differences between the two groups regarding their opinions' about effective error treatment practices. The implications of this study can be that teachers should take into account EFL learners' perceptions along with their anxiety levels when they embark on correcting their oral errors.

Keywords: oral corrective feedback; high anxiety group; low anxiety; opinion; Iranian EFL learners 


\section{Iranian EFL learners' preferred oral corrective feedback: High anxious learners vs. low anxious learners}

\section{Introduction}

The role of oral corrective feedback (CF) in language acquisition has been a highly controversial issue. Whereas some believe that exposing learners to naturally occurring samples of a target language is the only way to develop second language, others argue that error treatment is harmful rather than helpful (Krashen 1982; Schwartz1993; Truscott 1999). Lewis (2002) classified the purposes for oral CF in four categories: 1) it provides learners with advice about learning and it also helps them to acquire some kind of language input as they might learn new vocabulary and structures in context, 2) it provides information for both teachers and students as it paves ways for teachers to describe their learners' language, and for learners to be assessed with more precision than marks or grades, 3) it is a form of motivation as it can encourage learners to study and do their best, and 4) it is one step forward towards self-reliance as learners may start detecting their own mistakes (cited in Al-Faki, 2013, p. 224).

The extent of these values, however, can vary for different individuals with different individual characteristics, such as foreign language anxiety. According to Horwitz, Horwitz, and Cope (1986), Foreign Language Anxiety (FLA) is "a distinct complex of self-perceptions, beliefs, feeling, and behaviors related to classroom language learning arising from the uniqueness of the (foreign) language learning process" (p.128). It should be borne in mind that FLA is different from state anxiety, which happens in specific and temporary conditions and abolishes when the threat (or situation) disappears (Speilberger \& Vagg, 1995). It is also distinguished from trait anxiety, which is a stable individual difference. As Ellis (2008) contends, people with high level of trait anxiety have a general inclination to become anxious in any situation. FLA anxiety is a situation-specific concept and always is divergent from the two other types of anxiety, that is, state and trait anxiety. According to Tseng (2012):

The use of modern communicative language teaching approaches in the language classrooms and the wide-spread use of English language have increased the demand to learn good communication skills but existence of such feelings in the learners may prevent them from achieving the desired goal (p. 75).

It is now a common belief that making errors is a natural and inevitable occurrence in a language learning process (Corder, 1967). Therefore, one of the significant and stimulating areas of research for educators and researchers would be learners' preferred oral CF on those errors with reference to their FLA levels: high anxious vs. low anxious learners. Such opinions and perceptions about errors and corrective feedback are fundamental and can contribute to the language learning process.

\subsection{Learners' Opinions about Oral Corrective Feedback}

Research shows that there are differences between teachers' perceptions and teaching practices and learners' opinions and learning preferences with regard to error correction (e.g. Oladejo, 1993; Schulz, 1996). Horwitz (1988) maintains that teachers in order to be able to cultivate more effective learning strategies in their learners need to know their learners' beliefs about language learning because there may be an incongruence between learners' expectations about language learning and the realties they face in a classroom context, which can thwart language learning.

According to Nunan (1988), "one of the most serious blocks to learning is the mismatch between teacher and learner expectations about what should happen in the classroom"(p. 177). Many researchers (e.g. 
Hendrickson, 1978; Nunan, 1988; Horwitz, 1988; Katayama, 2007; Schulz, 1996, 2001; Yoshida, 2008) argue that understanding and matching the dissimilarities between the expectations of teachers and those of learners is an important factor which determines the success of a language learning process. Due to the fact that presence of such a gap between teachers' and learners' perceptions towards errors and error correction practices can lead to unfavorable learning outcomes (e.g., Green, 1993; Horwitz, 1988; McCargar, 1993; Nunan, 1988; Schulz, 2001), therefore, it is beneficial for teachers to realize their learners' opinions and expectations about instructional practices because "teachers should find out what their students think and feel about what and how they want to learn" (Nunan 1995, p. 140).

As Ayedh and Khaled (2012) reasoned, emotions and feelings towards the process of feedback was primarily reliant on how it was actually managed. They maintained that corrective feedback could only be used to a limited point, after which provision of it could become destructive and discouraging, even though too little oral CF could be equally counterproductive. Ayedh and Khaled (2012) put forward that "Feedback should always be personal and never directed at the person's personality" (p. 216). As Storch (2010) contends, delivery of corrective feedback "on a large number of errors may overwhelm the learners, not to mention be extremely time consuming for the teachers" (p. 430).

\subsection{Types of Corrective Feedback}

In their study on form instruction in content-based context of French immersion classrooms, Lyster and Ranta (1997) identified different types of corrective feedback. According to the findings of this study, they identified six types of CF: explicit correction, recast, clarification requests, meta-linguistic clue, elicitation and repetition of error. These types are classified into two major categories on the basis of whether they are explicit or implicit in nature. As Ellis, Loewen, and Erlam (2006) argue, in explicit feedback types there is an overt indication that an error has been occurred; while in implicit ones there is no overt indication that an error has been occurred. Lyster (1998) categorized these types of feedback as recasts, explicit correction and negotiation of form which involves the elicitation, metalinguistic clue, clarification request and repetition. In the case of recasts and explicit correction the teacher gives the correct form of the error. But, in the first case, correction is done implicitly whereas, in the second one, it is done explicitly. With regard to negotiation of form, it can be seen that the TL form is not given and the teacher simply gives a hint that the utterance of the student includes an error and therefore prompts the correct form. That is why this category is also called prompts.

Recast - According to Lyster and Ranta (1997), recast can be defined as "the teacher's reformulation of all or part of a student's utterance, minus the error" (p. 46).

Example:

S: she has 20 years old.

T: she is 20 years old.

Explicit correction - According to Lyster and Ranta (1997), explicit correction, like recast, provides the language learners with the correct forms of their ill-formed target utterances. Furthermore, it encompasses more information to specify that the learners' utterance was ill-formed; therefore, it is explicit in comparison with recast which is implicit.

Example:

S: He go to school every day.

T: It's not "he go", but "he goes".

Clarification request - According to Lyster and Ranta (1997), clarification request is defined as an indication to learners either that the teacher has misconstrued the utterance or that it was ill-formed and accordingly "a repetition or reformulation is required" (p. 47). They maintain that this kind of feedback relates either to problems of "comprehensibility or accuracy, or both". 
Abedi, D., Mahdavi, Z., \& Hassaskhah, J.

Example:

S: How many years does she have?

T: Pardon me?

Metalinguistic clues - In metalinguistic feedback, according to Lyster and Ranta (1997), the teacher does not give the correct form but "comments, information, or questions related to the well-formedness of the students' utterance" (p. 47).

Example:

S: There are many policeman on the street.

T: You need plural.

Repetition - Repetition denotes to the technique of repeating the student's ill-formed utterance in isolation.

Example:

S: She eated her lunch.

T: She Eated her lunch.

Elicitation - It involves three strategies which teachers use to directly elicit the correct form from the learner: 1) Eliciting completion of their own utterance by "pausing to allow them to fill the blank", 2) using questions to elicit the correct forms, and 3) asking students to reformulate their utterance (Lyster \& Ranta, 1997, p. 48).

Example:

T: The child found his mother after a small time.

S: After a ...

Lochtman (2002) in her study tried to investigate the frequency and distribution of corrective feedback types along with types of learner uptake. Her concentration was on the function of oral corrective feedback within an analytic context of foreign language classroom interaction. The results showed that recasts and elicitations were the most popular types of feedback, respectively. In addition, the results indicated that recasts and explicit corrections were the least effective types of corrective feedback considering learners uptake, and metalinguistic feedback and elicitations were the most effective movements by teachers which lead into learner uptake.

Surakka (2007) in a similar study investigated the frequency and effectiveness of various corrective feedback types in Finnish EFL classrooms. The results of her study showed that although teachers used recast as the most frequent type of corrective feedback, the findings indicated that recasts and explicit correction were not the most effective strategies in terms of learner uptake, but other types of corrective feedback such as elicitation and metalinguistic feedback were more successful strategies that led to learner uptake.

Sheen (2008) tried to investigate the effect of language anxiety as a factor on learners' ability to modify output from recasts. The results indicated that recasts were beneficial only to the low anxious learners. They argued that since recast as a corrective feedback strategy is an implicit and a nonthreatening strategy which provides the target form, it does not provoke anxiety. In addition the findings showed that low anxious learners in comparison to high anxious learner were able to produce higher levels of modified output from recasts. Sheen argued that communicative tasks could be a source of anxiety for learners because these types of tasks urged learners to be active in the course of communication. The results showed that anxiety was an important factor in determining the effectiveness of recasts which can improve the quality of learning.

Ahangari and Amirzadeh (2011) investigated the teachers' use of spoken corrective feedback in teaching Iranian EFL learners at different levels of proficiency. They used a database of 360 corrective feedback moves which two EFL teachers provided to their learners at three levels of proficiency. They identified eight types of corrective feedback and determined distribution of these types regarding learners' proficiency levels. The results indicated that recast was the most frequently used type of corrective feedback that teachers used at all three levels of proficiency. However, as the learners became more proficient teachers reduced recasts and used other techniques of corrective feedback. Salehi et al. (2013) in their study tried to find the impact of interactional 
feedback on Iranian EFL learners' anxiety in grammar learning. They used a foreign language classroom anxiety scale (FLCAS) (Horwitz et al., 1986) and a grammar test at both pre-test and post-test stages of the study. The experimental group received treatment based on interactional feedback (recast type) for one semester, but the control group received direct feedback (traditional way). After analyzing the data it was discovered that interactional feedback had a significant effect on Iranian EFL learners' anxiety with regard to grammar learning.

The studies cited above verify that oral $\mathrm{CF}$ is one of the most important techniques whose effect in real discourse events of a foreign language classroom has been largely debated. One of the important factors whose effect has been debated in this regard is oral corrective feedback. Besides, compatibility with the learners' individual differences (e.g., anxiety), opinions, and preferences is necessary for error correction to be corrective. That is, regarding the provision of corrective feedback, teachers should take into consideration the opinions and preferences of their learners and should provide corrective feedback in a way that motivates them to engage more in classroom interactions.

Although there are some studies in Iranian EFL context regarding corrective feedback and anxiety (e.g. Farrokhi, 2003; Rahimi, 2010; Jabbari \& Faziltfar, 2012; Rahimi \& Dastjerdi, 2012, Mahmoodzadeh, 2013; Mesri 2012; Salehi et al., 2013), there is no study to the researchers' knowledge to investigate the Iranian EFL learners' opinions on oral corrective feedback with regard to their level of classroom anxiety. Therefore, this study tried to fill the gap in the related literature and pave the way for the better understanding of corrective feedback and different factors that could influence it.

\section{Materials and methods}

This study employed a descriptive and quantitative approach to collect and analyze the data. Two sets of questionnaires were employed to elicit the required information across a sample of 200 Iranian EFL learners.

\subsection{Research Question}

The study addressed the general research question:

$>\quad$ What are Iranian EFL high anxious learners vs. low anxious learners' preferred oral correction practices?

\subsection{Participants}

The participants of this study were Iranian EFL learners from two language institutes in Ardabil, Iran. The institutes offer English courses at six levels: beginners, elementary, pre-intermediate, intermediate, upper-intermediate, and advanced levels. In this study, the total number of participants was originally $200 \mathrm{EFL}$ learners selected from among adult EFL learners in these two language institutes, whose proficiency level varied from intermediate to advanced level. Both male and female learners participated in this study (100 male and 100 female). The learners' ages ranged from 15 to 25 . As not all the classes in the two institutes were appropriate for the purpose of this study regarding the learners' proficiency level, age, and so on, opportunity or convenience sampling (non-probability sampling) was selected because of the easy accessibility to samples by the researchers and the willingness and availability of participants. In order to overcome the limitations of this technique, the researchers selected only those participants that were deemed to be appropriate and to represent the target population of EFL learners. The criterion for sampling was purposive which was on the basis of both researchers' and teachers' opinions regarding the aim of this study, i.e. only those learners who had the knowledge and capability to fill the questionnaire as easily and reliably as possible.

\subsection{Instruments}

Two questionnaires were used in this study: The first one which was adapted and modified from Fukuda 
Abedi, D., Mahdavi, Z., \& Hassaskhah, J.

(2004) was administered to Iranian EFL learners to investigate their opinions on error correction. The reason for using this questionnaire was that it was comprehensive and appropriate regarding the purpose of this study. This questionnaire had two sections. The first section was designed to collect demographic information of participants such as their age, gender, and proficiency level. The second section included eighteen items designed to investigate learners' opinions on the necessity, frequency, types of errors to be corrected, types of corrective feedback, and delivering agent of corrective feedback.

The second questionnaire was an anxiety questionnaire which was adapted and modified from Horwitz et al.'s (1986) Foreign Language Classroom Anxiety Scale (FLCAS). The reason for using this questionnaire was that it had been the most well-known instrument for measuring FL classroom anxiety over the last few decades due to its high validity and reliability. The modified questionnaire had two sections. The first section involved three items designed to elicit the required information about their demography, and the second section involved ten items designed to elicit the learners' attitudes towards different aspects of foreign language classroom anxiety, i.e., lack of confidence, communication apprehension, fear of making mistakes, and negative evaluation.

Before using these questionnaires as data collection tools, they were piloted for appropriacy for this research. Both sets of questionnaires were translated into Persian Language in order to avoid any potential confusion, misunderstanding or misinterpretation of items. In order to validate these Persian versions, two experts on translation were asked to validate them. The internal reliabilities of Persian versions of questionnaires were an alpha coefficient of 0.88 for the corrective feedback questionnaire and an alpha coefficient of 0.85 for the anxiety questionnaire, respectively.

\subsection{Procedure}

Distribution of questionnaires to participants was made personally by one of the researchers. Before the administration of questionnaires to the learners, they were informed that their participation was voluntary and the survey was anonymous. Furthermore, they were informed that they were free to withdraw at any time and for any reason. Since the questionnaires were distributed in the classrooms, the teachers were asked to leave the classroom in order to let the students feel comfortable as they were answering the questions. Each set of questionnaires was distributed separately and at different times to the same participants in order to provide them enough time to respond as well as they could. Distribution of questionnaires to the learners took place at the last thirty minutes of classes.

\subsection{Data Analysis}

The data gathered in this study was analyzed using the SPSS software version 19.0. Regarding FLCAS questionnaire, the gathered data were analyzed to identify participants with higher or lower levels of anxiety. The questionnaire had 10 items to be answered based on a five point Likert scale, a value of 1 was given to the response strongly disagree, and a value of 5 to strongly agree. In the case of negatively worded items (such as items 2, 9), the values were reversed, that is, a value of 1 was given to strongly agree, and a value of 5 to strongly disagree. By doing this, the researchers calculated each participant's anxiety score by adding his/her ratings of the whole 10 items. In this study, the scores of the FLCAs were interpreted as follows: The higher the participants' scores, the higher their level of anxiety and vice versa. In order to divide learners into either high anxiety or low anxiety group, the lowest score of the scale was added to the highest score of the scale, and then divided by two to gain the cut-off point (middle point). The middle point in this case was $30(10+50 / 2)$. Therefore, scores lower than 30 denote lower levels of anxiety, and score higher than 30 denote higher levels of anxiety.

After dividing the learners into two groups of anxiety on the basis of the cut-off point criteria, a Chi-square test was performed in order to determine whether there were statistically significant differences between these two groups regarding their opinions on error correction practices. Before performing Chi-square test, the ordinal 
Iranian EFL learners' preferred oral corrective feedback: High anxious learners vs. low anxious learners

data converted into nominal data and coded as "Yes" or "No", and then this test was run to find whether there were differences between two groups of anxiety or not.

\section{Results and Discussion}

Item 1 tried to investigate Iranian EFL learners' opinions on the necessity of error correction by raising the statement "I want to receive corrective feedback".

\subsection{Necessity of Error Correction}

\section{Table 1}

Results of Descriptive Statistics and Chi-square test of Learners' Responses to Necessity of Oral Error Correction

\begin{tabular}{|c|c|c|c|c|c|c|c|c|}
\hline & Group & Yes & No & Mean & SD & $\chi^{2}$ & $\mathrm{df}$ & $p$ \\
\hline \multirow{2}{*}{ Item 1} & $\begin{array}{c}\text { HA } \\
(n=119)\end{array}$ & \multirow{2}{*}{$\begin{array}{c}115 \\
96.4 \% \\
81 \\
100 \%\end{array}$} & $\begin{array}{c}4 \\
3.4\end{array}$ & 1.00 & .397 & \multirow[b]{2}{*}{125.663} & \multirow[b]{2}{*}{1} & \multirow[b]{2}{*}{0.000} \\
\hline & $\begin{array}{c}\text { LA } \\
(n=81)\end{array}$ & & $\begin{array}{c}0 \\
0.0 \%\end{array}$ & 1.81 & .399 & & & \\
\hline
\end{tabular}

Note. ${ }^{*} p=0.000<0.05$

As the results of chi-square test represent, there were significant differences between the two anxiety groups regarding the necessity of error correction, $\chi^{2}(1,200)=125.663, P=0.000<0.05$. The results contradict Park's (2010), that there were no significant differences between the high anxious and the low anxious learners.

\subsection{Frequency of Receiving Corrective Feedback}

Regarding the differences between the two groups of anxiety on their opinions about the frequency of error correction, the results in Table 2 indicate that there was a significant difference between the two groups of anxiety.

Table 2

Results of Descriptive Statistics and Chi-square Test of Learners' Opinions about Frequency of Oral Correction

\begin{tabular}{|c|c|c|c|c|c|c|c|c|}
\hline & Group & YES & $\mathrm{NO}$ & Mean & Std. D & $\chi^{2}$ & df & $p$ \\
\hline \multirow[b]{2}{*}{ Item 2} & $\begin{array}{c}\text { HA } \\
(n=119)\end{array}$ & $\begin{array}{c}52 \\
43.7 \%\end{array}$ & $\begin{array}{c}95 \\
56.3 \%\end{array}$ & 1.80 & .403 & 104.596 & \multirow[b]{2}{*}{1} & \multirow[b]{2}{*}{0.000} \\
\hline & $\begin{array}{c}\text { LA } \\
(n=81)\end{array}$ & $\begin{array}{c}76 \\
93.8 \%\end{array}$ & $\begin{array}{l}5 \\
6.2 \%\end{array}$ & 1.06 & .242 & & & \\
\hline
\end{tabular}

Note. ${ }^{*} p<0.05$

\subsection{Types of Errors that Should Be Corrected}

As Table 3 shows, there were significant differences between the learners' opinions regarding types of errors that should be corrected. The low anxious learners wanted to receive corrective feedback regarding local errors more than their counterparts in the high anxiety group. These findings were in contrast with those of Park (2010), where there were no significant differences between the opinions of the high anxious learners and those of the low anxious learners regarding types of errors. 
Abedi, D., Mahdavi, Z., \& Hassaskhah, J.

Table 3

Results of Descriptive statistics and Chi-square Test for Types of Errors that should be Corrected.

\begin{tabular}{|c|c|c|c|c|c|c|c|c|}
\hline & Group & Yes & No & Mean & Std. D & $\chi^{2}$ & df & $p$ \\
\hline \multirow{4}{*}{ Item 3} & $\mathrm{HA}$ & 69 & 50 & 1.42 & .496 & \multirow{4}{*}{31.057} & \multirow{4}{*}{1} & \multirow{4}{*}{0.000} \\
\hline & $(n=119)$ & $57.9 \%$ & $42.1 \%$ & & & & & \\
\hline & LA & 76 & 5 & & & & & \\
\hline & $(n=81)$ & $93.9 \%$ & $6.1 \%$ & 1.06 & .242 & & & \\
\hline \multirow{4}{*}{ Item 4} & HA & 10 & 109 & 1.92 & .279 & \multirow{4}{*}{67.680} & \multirow{4}{*}{1} & \multirow{4}{*}{0.000} \\
\hline & $(n=119)$ & $8.4 \%$ & $91.6 \%$ & & & & & \\
\hline & LA & 51 & 30 & & & & & \\
\hline & $(81)$ & $62.9 \%$ & $37.1 \%$ & 1.37 & .486 & & & \\
\hline \multirow{4}{*}{ Item 5} & HA & 29 & 90 & 1.76 & .431 & \multirow{4}{*}{60.408} & & \multirow{4}{*}{0.000} \\
\hline & $(n=119)$ & $24.3 \%$ & $75.7 \%$ & & & & \multirow{3}{*}{1} & \\
\hline & LA & 65 & 16 & & & & & \\
\hline & (81) & $80.3 \%$ & $19.7 \%$ & 1.20 & .401 & & & \\
\hline \multirow{4}{*}{ Item 6} & HA & 16 & 103 & 1.87 & .343 & \multirow{4}{*}{7.890} & \multirow{4}{*}{1} & \multirow{4}{*}{0.005} \\
\hline & $(n=119)$ & $13.5 \%$ & $86.5 \%$ & & & & & \\
\hline & LA & 24 & 57 & & & & & \\
\hline & $(n=81)$ & $24.6 \%$ & $75.4 \%$ & 1.70 & .459 & & & \\
\hline \multirow{4}{*}{ Item 7} & $\mathrm{HA}$ & 58 & 61 & 1.51 & .502 & \multirow{4}{*}{39.010} & \multirow{4}{*}{1} & \multirow{4}{*}{0.000} \\
\hline & $(n=119)$ & $48.8 \%$ & $51.2 \%$ & & & & & \\
\hline & LA & 74 & 7 & & & & & \\
\hline & (81) & $91.9 \%$ & $8.1 \%$ & 1.09 & .283 & & & \\
\hline
\end{tabular}

\subsection{Corrective Feedback Strategies}

Considering the opinions of the two groups on corrective feedback strategies, the results of chi-squares show that there were significant differences between the high anxious learners and the low anxious learners regarding items 8-15. The results of this study were not in keeping with the findings from Park (2010), where there were not significant differences between the two groups of anxiety regarding their opinions about methods of error correction, but were in line with those of Renko (2012), where there were significant differences between the high anxious learners and the low anxious learners considering their opinions about error correction methods.

As Table 4 shows, the most effective methods of oral error correction from learners' points of view regardless of their anxiety level were strategies of implicit correction, elicitation, and recast and the strategy of "no corrective feedback" was considered the least effective method of oral error correction.

\section{Table 4}

Results Descriptive Statistics and Chi-square Tests for Corrective Feedback Strategies

\begin{tabular}{|c|c|c|c|c|c|c|c|c|}
\hline & Group & Yes & No & Mean & Std. D & $\chi^{2}$ & $\mathrm{df}$ & $p$ \\
\hline \multirow{4}{*}{ Item 8} & HA & 79 & 40 & 1.34 & .474 & \multirow{4}{*}{13.193} & \multirow{4}{*}{1} & \multirow{4}{*}{0.000} \\
\hline & $(n=119)$ & $66.4 \%$ & $33.6 \%$ & & & & & \\
\hline & LA & 72 & 9 & & & & & \\
\hline & $(n=81)$ & $88.8 \%$ & $11.2 \%$ & 1.11 & .316 & & & \\
\hline \multirow{4}{*}{ Item 9} & HA & 48 & 71 & 1.60 & .493 & \multirow{4}{*}{39.930} & \multirow{4}{*}{1} & \multirow{4}{*}{0.000} \\
\hline & $(n=119)$ & $40.4 \%$ & $59.6 \%$ & & & & & \\
\hline & LA & 69 & 12 & & & & & \\
\hline & $(n=81)$ & $85.2 \%$ & $14.8 \%$ & 1.15 & .357 & & & \\
\hline \multirow{4}{*}{ Item 10} & HA & 101 & 18 & 1.15 & .380 & \multirow{4}{*}{6.853} & \multirow{4}{*}{1} & \multirow{4}{*}{0.029} \\
\hline & $(n=119)$ & $82.9 \%$ & $17.1 \%$ & & & & & \\
\hline & LA & 74 & 7 & & & & & \\
\hline & $(\mathrm{n}=81)$ & $91.4 \%$ & $8.6 \%$ & 1.09 & .230 & & & \\
\hline
\end{tabular}


Table 4 ... continued

\begin{tabular}{|c|c|c|c|c|c|c|c|c|}
\hline & Group & Yes & No & Mean & Std. D & $\chi^{2}$ & df & $p$ \\
\hline \multirow{2}{*}{ Item 11} & $\begin{array}{c}\text { HA } \\
(n=119)\end{array}$ & $\begin{array}{c}57 \\
479 \%\end{array}$ & $\begin{array}{c}62 \\
521 \%\end{array}$ & 1.52 & .502 & \multirow[b]{2}{*}{24.797} & \multirow[b]{2}{*}{1} & \multirow[b]{2}{*}{0.000} \\
\hline & $\begin{array}{c}\text { LA } \\
(n=81)\end{array}$ & $\begin{array}{c}67 \\
82.7 \%\end{array}$ & $\begin{array}{c}14 \\
17.3 \%\end{array}$ & 1.17 & .380 & & & \\
\hline \multirow{3}{*}{ Item 12} & HA & 96 & 23 & 1.19 & .397 & \multirow{3}{*}{4.316} & \multirow{3}{*}{1} & \multirow{3}{*}{0.038} \\
\hline & $(n=119)$ & $80.7 \%$ & $19.3 \%$ & & & & & \\
\hline & $(\mathrm{n}=81)$ & $91.3 \%$ & $8.7 \%$ & 1.09 & .283 & & & \\
\hline \multirow{4}{*}{ Item 13} & $\mathrm{HA}$ & 29 & 90 & 1.76 & .431 & \multirow{4}{*}{11.310} & \multirow{4}{*}{1} & \multirow{4}{*}{0.001} \\
\hline & $(n=119)$ & $24.3 \%$ & $76.7 \%$ & & & & & \\
\hline & LA & 5 & 76 & & & & & \\
\hline & $(n=81)$ & $6.2 \%$ & $93.8 \%$ & 1.94 & .242 & & & \\
\hline \multirow{4}{*}{ Item 14} & HA & 86 & 33 & 1.28 & .450 & \multirow{4}{*}{9.427} & \multirow{4}{*}{1} & \multirow{4}{*}{0.002} \\
\hline & $(n=119)$ & $72.2 \%$ & $27.8 \%$ & & & & & \\
\hline & LA4 & 73 & 8 & & & & & \\
\hline & $(n=81)$ & $90.1 \%$ & $9.9 \%$ & 1.10 & .300 & & & \\
\hline \multirow{4}{*}{ Item 15} & HA & 76 & 43 & 1.36 & .482 & \multirow{4}{*}{10.987} & \multirow{4}{*}{1} & \multirow{4}{*}{0.001} \\
\hline & $(n=119)$ & $63.9 \%$ & $36.1 \%$ & & & & & \\
\hline & LA & 69 & 12 & & & & & \\
\hline & $(n=81)$ & $85.1 \%$ & $14.9 \%$ & 1.15 & .357 & & & \\
\hline
\end{tabular}

\subsection{Providers of Corrective Feedback}

Results of chi-square tests indicate that there were significant differences between the two anxiety groups regarding their opinions on different sources of error correction. Regarding teachers as the primary source of feedback, the majority of the low anxious learners strongly agreed to be corrected by their teacher. As Table 5 shows, there were significant differences between the high anxious learners and the low anxious learners considering their opinions about peer correction. Regarding the first category, the findings of this study were not in keeping with the results of Park's study (2010), where there were not significant differences between the two anxiety group regarding teachers as the primary source of feedback. In the case of "self-correction", the results were the same as the findings of Park (2010) and Renko (2012), where there were significant differences between the high anxious and the low anxious learners. With regard to "peer correction", the findings of this study are unlike the results of Park's study (2010), where there were not significant differences between the two anxiety groups regarding classmates as the source of feedback.

Table 5

Results of Descriptive Statistics and Chi-square Tests for Providers of Corrective Feedback

\begin{tabular}{|c|c|c|c|c|c|c|c|c|}
\hline & Group & Yes & No & Mean & Std. D & $\chi^{2}$ & $\mathrm{df}$ & $p$ \\
\hline \multirow[b]{2}{*}{ Item 16} & $\begin{array}{c}\text { HA } \\
(n=119)\end{array}$ & $\begin{array}{c}27 \\
226 \%\end{array}$ & $\begin{array}{c}92 \\
774 \%\end{array}$ & 1.77 & .421 & \multirow[b]{2}{*}{64.278} & \multirow[b]{2}{*}{1} & \multirow[b]{2}{*}{0.000} \\
\hline & $\begin{array}{c}\text { LA } \\
(n=8)\end{array}$ & $\begin{array}{c}65 \\
80.3 \%\end{array}$ & $\begin{array}{c}16 \\
19.7 \%\end{array}$ & 1.20 & .401 & & & \\
\hline \multirow{3}{*}{ Item 17} & HA & 96 & 23 & 1.19 & .397 & \multirow{3}{*}{12.524} & \multirow{3}{*}{1} & \multirow{3}{*}{0.000} \\
\hline & $\frac{(n=119)}{L A}$ & $\begin{array}{c}80.7 \% \\
79\end{array}$ & $\begin{array}{c}19.3 \% \\
2\end{array}$ & & & & & \\
\hline & $(n=8)$ & $97.5 \%$ & $2.5 \%$ & 1.02 & .156 & & & \\
\hline \multirow{4}{*}{ Item 18} & HA & 98 & 21 & 1.89 & .583 & \multirow{4}{*}{11.657} & \multirow{4}{*}{1} & \multirow{4}{*}{0.001} \\
\hline & $(n=119)$ & $82.3 \%$ & $17.6 \%$ & & & & & \\
\hline & LA & 64 & 17 & & & & & \\
\hline & $(n=8)$ & $79.1 \%$ & $20.9 \%$ & 1.20 & .210 & & & \\
\hline
\end{tabular}


Considering types of errors, methods of corrective feedback, and providers of corrective feedback, the findings of this study do not support those of findings of Park's (2010) study, where there were no statistically significant differences between the two anxiety groups.

\section{Conclusion}

Irrespective of their level of anxiety, the learners in both groups wanted to receive corrective feedback when they committed oral error. Among the types of errors that needed to be corrected, serious spoken errors were considered the most important type of errors. Of the strategies of corrective feedback, elicitation, implicit correction, and recast were the three most effective methods for both groups of the anxiety, and "no corrective feedback" was the least effective method for both high anxious and low anxious learners. Regarding "delivering agents of corrective feedback", majority of the learners in both anxiety groups regarded teachers as the prime providers of feedback, while peer correction was considered the least effective category regarding providers of feedback.

Regarding types of errors, teachers should not correct all of the errors that learners commit in their speaking, but rather give the prominence to the more serious errors, the ignoring of which can cause breakdowns in the interlocutors' understanding. In providing corrective feedback, it is incumbent upon the teachers to use different error correction strategies to cater for differences in the learners' preferences, i.e. the strategies which are more facilitative rather than debilitative. The last but not the least is that the teachers should always pay attention to learners' individual differences such as anxiety, motivation in order to be as much helpful as they can in paving the way for them to learn better.

\section{References}

Ahangari, S., \& Amirzadeh, S. (2011). Exploring the teachers' use of spoken corrective feedback in teaching Iranian EFL learners at different levels of proficiency. In International Conference on Education and Educational Psychology (pp. 1859-1868). http://dx.doi.org/10.1016/j.sbspro.2011.11.435

Al-Faki, I. M. (2013). The effect of timely interference of English language teachers on the improvement of learners' oral performance. International Journal of Applied Linguistics \& English Literature, 2(6), 222-235. http://dx.doi.org/10.7575/aiac.ijalel.v.2n.6p.222

Allwright, D., \& Bailey, K. (1991). Focus on the language classroom: An introduction to classroom research for language teachers. Cambridge: Cambridge University Press.

Ayedh, A., \& Khaled, E. (2011). EFL teachers' feedback to oral errors in EFL classroom: Teachers' perspectives. Arab World English Journal, 2(1), 214-232.

Bartman, M., \& Walton, R. (1991). Correction. A positive approach to language mistakes. Hove: LTP.

Broughton, G., Brumfit, Ch., Pincas, A., \& Wilde, R. D. (2003). Teaching English as a foreign language. New York: Routledge.

Brown, H. D. (2007). Principles of language learning and teaching. New York. Pearson Education.

Carroll, S. E., \& Swain, M. (1993). Explicit and implicit negative feedback: An empirical study of learning of linguistic generalizations. Studies in Second Language Acquisition, 15, 357-386. http://dx.doi.org/10.1017/S0272263100012158

Chaudron, C. (1977). A descriptive model of discourse in the corrective treatment of learners' errors. Language Learning, 27(1), 29-46. http://dx.doi.org/10.1111/j.1467-1770.1977.tb00290.x

Corder, S. (1967). The significance of learners' errors. International Review of Applied Linguistics, 5, 161-167.

Doff, A. (1993). Teach English. Cambridge: Cambridge University Press.

Edge, J. (1989). Mistakes and correction. Harlow: Longman.

Ellis, R. (2008). The study of second language acquisition (2nd Ed.). Oxford: Oxford University Press.

Ellis, R., \& Sheen, Y. (2006). Re-examining the role of recasts in L2 acquisition. Studies in Second Language Acquisition, 28, 575-600. http://dx.doi.org/10.1017/S027226310606027X 
Iranian EFL learners' preferred oral corrective feedback: High anxious learners vs. low anxious learners

Ellis, R., Loewen, S., \& Erlam, R. (2006). Implicit and explicit corrective feedback and the acquisition of L2 grammar. Studies in Second Language Acquisition, 28(2), 339-368. http://dx.doi.org/10.1017/S0272263106060141

Farrokhi, F. (2003). A context-based study of varieties of corrective feedback in EFL classrooms. Published doctoral dissertation. Retrieved from http://www.irandoc.ac.ir

Fukuda, Y. (2004). Treatment of spoken errors in Japanese high school oral communication classes. Published Masteral thesis, California State University, San Francisco.

Green, J. M. (1993). Student attitudes toward communicative and non-communicative activities: Do enjoyment and effectiveness go together? The Modern Language Journal, 77(1), 1-10. http://dx.doi.org/10.1111/j.1540-4781.1993.tb01938.x

Hampl, M. (2011). Error and error correction in classroom conversation - A comparative study of CLIL and traditional EFL lessons in Austria. Unpublished masteral thesis, University of Vienna, Austria.

Hendrickson, J. M. (1978). Error correction in foreign language teaching: Recent theory, research, and practice. The Modern Language Journal, 62(8), 387-398.

Horwitz, E. K. (1988). The beliefs about language learning of beginning university foreign language students. The Modern Language Journal, 72, 283-294. http://dx.doi.org/10.1111/j.1540-4781.1988.tb04190.x

Horwitz, E., Horwitz, B., \& Cope, J. (1986). Foreign language classroom anxiety. Modern Language Journal, 70, 125-132. http://dx.doi.org/10.1111/j.1540-4781.1986.tb05256.x

Jabbari, A. A., \& Faziltfar, A. M. (2012). The role of error types and feedback in Iranian EFL classrooms. International Journal of English Linguistics, 2(1), 135-148. http://dx.doi.org/10.5539/ijel.v2n1p135

Katayama, A. (2007). Learners' perceptions toward oral error correction. In K. Bradford-Watts (Ed.), JALT2006 Conference Proceedings. Tokyo: JALT.

Krashen, S. (1982). Principles and practice in second language acquisition. Oxford: Pergamon Press.

Lochtman, K. (2002). Oral corrective feedback in the foreign language classroom: How it affects interaction in analytic foreign language teaching. International Journal of Educational Research, 37, 271-283. http://dx.doi.org/10.1016/S0883-0355(03)00005-3

Lyster, R. (1998). Recasts, repetition, and ambiguity in L2 classroom discourse. Studies in Second Language Acquisition, 20, 51-81. http://dx.doi.org/10.1017/S027226319800103X

Lyster, R., \& Ranta, L. (1997). Corrective feedback and learner uptake. Studies in Second Language Acquisition, 20, 37-66. http://dx.doi.org/10.1017/s0272263197001034

Mahmoodzadeh, M. (2011). Investigating foreign language anxiety in Iranian classrooms: The effect of gender. International Journal of Research Studies in Language Learning, 2(1), 61-70.

McCargar, D. F. (1993). Teacher and student role expectations: Cross-cultural differences and implications. The Modern Language Journal, 77(2), 192-207. http://dx.doi.org/10.1111/j.1540-4781.1993.tb01963.x

Mesri, F. (2012). The relationship between gender and Iranian EFL learners' foreign language classroom anxiety (FLCA). International Journal of Academic Research in Business and Social Sciences, 2(6), 147-156.

Nicholas, H., Lightbown, P., M., \& Spada, N. (2001). Recasts as feedback to language learners. Language Learning, 51(4), 719-758. http://dx.doi.org/10.1111/0023-8333.00172

Nunan, D. (1988). The learner-centered classroom. Cambridge: Cambridge University Press.

Nunan, D. (1995). Closing the gap between learning and instruction. TESOL Quarterly, 29(1), 133-158. http://dx.doi.org/10.2307/3587808

Oladejo, J. A. (1993). Error correction in ESL: Learners' preference. TESL Canada Journal, 10(2), 71-89.

Park, H. S. (2010). Teachers' and learners' preferences for error correction. Published Masteral thesis, California State University, Sacramento.

Rahimi, A., \& Dastjerdi, H., V. (2012). Impact of immediate and delayed error correction on EFL learners' oral production: CAF. Mediterranean Journal of Social Sciences, 3(1), 45-54.

Renko, K. (2012). Finnish EFL learners' perceptions on errors, corrective feedback and foreign language anxiety. Published Masteral thesis.

Richards, J. C., \& Renandya, W. A. (2002). Methodology in language teaching: An anthology of current practice. Cambridge: Cambridge University Press. http://dx.doi.org/10.1017/CBO9780511667190 
Abedi, D., Mahdavi, Z., \& Hassaskhah, J.

Russell, J., \& Spada, N. (2006). The effectiveness of corrective feedback for second language acquisition: A meta-analysis of the research. In J. Norris \& L. Ortega (Eds.), Synthesizing research on language learning and teaching (pp. 131-164).Amsterdam: Benjamins.

Salehi, Z., Jahandar, Sh., \& Khodabandehlou, M. (2013). The impact of interactional feedback on Iranian EFL learner's anxiety in grammar learning. Indian Journal of Fundamental and Applied Life Sciences, 3(2), 164-175.

Savignon, S. J. (1997). Communicative competence: Theory and classroom practice. New York: McGraw-Hill.

Schulz, R. A. (1996). Focus on form in the foreign language classroom: Students' and teachers' views on error correction and the role of grammar. Foreign Language Annals, 29(3), 343-364. http://dx.doi.org/10.1111/j.1944-9720.1996.tb01247.x

Schulz, R. A. (2001). Cultural differences in student and teacher perceptions concerning the role of grammar instruction and corrective feedback: USA-Columbia. The Modern Language Journal, 85(2), 244-258. http://dx.doi.org/10.1111/0026-7902.00107

Schwartz, B. (1993). On explicit and negative data effecting and affecting competence and linguistic behavior. Studies in Second Language Acquisition, 15, 147-163. http://dx.doi.org/10.1017/S0272263100011931

Scrivener, J. (2005). Learning teaching. Oxford: Macmillan.

Sheen, Y. (2008). Recasts, language anxiety, modified output, and L2 learning. Language Learning, 58(4), 835-874. http://dx.doi.org/10.1111/j.1467-9922.2008.00480.x

Spada, N., \& Fröhlich, M. (1995). Communication orientation of language teaching observation scheme. Coding conventions and applications. Sidney: National Centre for English Language Teaching and Research.

Spielberger, C. D., \& Vagg, P. (Eds.). (1995). Test anxiety: A transactional process model, test anxiety theory, assessment, and treatment. Washington, D.C.: Taylor \& Francis.

Storch, N. (2010). Critical feedback on written corrective feedback research. International Journal of English Studies, 10(2), 29-46.

Surakka, K. (2007). Corrective feedback and learner uptake in an EFL classroom. Published masteral thesis, University of Jyväskylä, Finland.

Tomkova, G. (2013). Error correction in spoken practice. Published masteral thesis, Masaryk University.

Truscott, J. (1999). What's wrong with oral grammar correction. The Canadian Modern Language Review, 55(4), 437-455. http://dx.doi.org/10.3138/cmlr.55.4.437

Tseng, S. F. (2012): The factors cause language anxiety for ESL/EFL learners in learning speaking. WHAMPOA - An Interdisciplinary Journal, 63, 75-90.

Yoshida, R. (2008). Teachers' choice and learners' preference of corrective feedback types. Language Awareness, 17(1), 78-93. http://dx.doi.org/10.2167/la429.0 